\title{
Profiles of SARS-CoV-2 RNA and Antibodies in Inpatients with COVID- 19 not Related with Clinical Manifestation: A Single Centre Study
}

\author{
Li Zhao ${ }^{1} \cdot$ Ruqin Gao ${ }^{2} \cdot$ Roujian $\mathrm{Lu}^{1} \cdot$ Huijuan Wang ${ }^{1} \cdot$ Yao Deng ${ }^{1} \cdot$ Peihua Niu ${ }^{1} \cdot$ Fachun Jiang ${ }^{2} \cdot$ \\ Baoying Huang ${ }^{1} \cdot$ Jiwei Liang ${ }^{2} \cdot$ Jing $\mathrm{Jia}^{2} \cdot$ Feng $\mathrm{Zhang}^{2} \cdot$ Wenling Wang ${ }^{1}$ (1) Guizhen $\mathrm{Wu}^{1,3}$ (I) \\ Wenjie $\operatorname{Tan}^{1,3}$
}

Received: 13 August 2020 / Accepted: 30 April 2021 / Published online: 1 July 2021

(c) Wuhan Institute of Virology, CAS 2021

Dear Editor,

A novel coronavirus disease (COVID-19) caused by acute respiratory syndrome coronavirus 2 (SARS-CoV-2) first broke out in Wuhan, Hubei Province, China, in 2019. More than 50 million cases of COVID-19 have been confirmed globally with $1,280,868$ deaths reported as of November 12, 2020 (https://covid19.who.int/). RNA detection based on real-time reverse transcription polymerase chain reaction (rRT-PCR) assay has been developed and is widely used as the standard of diagnosing COVID-19 (Chinese Center for Disease Control and Prevention 2020). SARSCoV-2 RNA can be detected from various types of specimens, with respiratory specimens mostly preferred (Pan et al. 2020b; To et al. 2020; Wang et al. 2020a; Xu et al. 2020; Zou et al. 2020). However, more data are needed to understand the profiles of viral shedding in different types of specimens from COVID-19 patients with different clinical manifestations. Antibody detection plays an important role in identifying the clinical status and outcome of a patient. Although several studies on antibody

Li Zhao, Ruqin Gao, Roujian Lu, Huijuan Wang, and Yao Deng have contributed equally to this work.

\footnotetext{
Wenjie Tan

tanwj@ivdc.chinacdc.cn

$\triangle$ Guizhen $\mathrm{Wu}$

wugz@ivdc.chinacdc.cn

$\triangle$ Wenling Wang

wangwl@ivdc.chinacdc.cn

1 NHC Key Laboratory of Biosafety, National Institute for Viral Disease Control and Prevention, Chinese Center for Disease Control and Prevention, Beijing 102206, China

2 Qingdao Center for Disease Control and Prevention, Qingdao 266033, China

3 Center for Biosafety Mega-Science, Chinese Academy of Sciences, Wuhan 430071, China
} 
viral loads using conversion factors, in accordance with the method in Niu et al. (2020). Nasopharyngeal swab and sputum samples had the highest viral loads, up to $2.9 \times 10^{6}$ copies $/ \mathrm{mL}$ (mean, $1.6 \times 10^{6}$ copies $/ \mathrm{mL}$ ) and $1.3 \times 10^{6}$ copies $/ \mathrm{mL}$ (mean, $1.1 \times 10^{6}$ copies $/ \mathrm{mL}$ ), respectively, substantially higher than the maximum load of 231 copies $/ \mathrm{mL}$ (mean, 54 copies $/ \mathrm{mL}$ ) recorded in faecal specimens (Fig. 1A, left). Most nasopharyngeal swabs (95\%, 18 of 19 tested) and all sputum samples (15 tested) had detectable viral loads in week 1, compared with $22 \%$ of the faecal samples (Fisher's exact test, $P<0.001$; Fig. 1A). Positive test rates did not differ among the three types of samples starting in week 2 after symptom onset (Fig. 1A, left). No positive results were obtained from urine $(n=13)$, blood $(n=17)$, or conjunctival swab $(\mathrm{n}=10)$ samples.

Viral loads of nasopharyngeal swab did not differ in COVID-19 patients with different illness stage, nor that of sputum, or faecal samples. The positive rate from nasopharyngeal swab samples decreased significantly, to $43 \%$, in week 3 after symptom onset compared to the rate in week 1 (Fisher's exact test, $P<0.05$ ). Similarly, positive rates from sputum samples decreased significantly, from $100 \%$ to $14 \%$, from both weeks 1 and 2 to week 3 after symptom onset (Fisher's exact test, $P<0.001$ and $P<0.01$, respectively). Furthermore, the average viral loads in COVID-19 patients with different clinical manifestations were assessed (Fig. 1A, right). For nasopharyngeal swab, sputum, and faecal samples, the average viral loads did not differ among patients (Fig. 1A, right). However, nasopharyngeal swabs collected from patients with mild disease status produced higher positive test rates compared with faecal samples (Fisher's exact test, $P<0.05)$. The proportion of positive tests differed more markedly among nasopharyngeal swab, sputum, and faecal samples collected from patients with moderate disease status (Fisher's exact test, $P<0.01$ ).

To determine the antibody levels in serum samples, an enzyme-linked immunosorbent assay (ELISA) was performed in-house by coating ELISA plates with commercial RBD (Sino Biological Inc., Beijing, China) to detect immunoglobulin (Ig) M and IgG serum samples. The cutoff value was set at three standard deviations above the mean value of the negative cohort. A SARS-CoV-2 pseudovirus particle neutralisation test ( $\mathrm{ppNT}$ ) was performed to detect neutralizing antibody (NAb) as previously described (Nie et al. 2020; Wang et al. 2019, 2016). The median seroconversion times for $\operatorname{IgM}, \mathrm{IgG}$, and NAb were 14 (1-37), 16 (1-49), and 14 (1-45) days after symptom onset, respectively. Seroconversion of IgM, IgG, and NAb were observed in 21,28 and 41 serum samples, respectively, that of both $\operatorname{IgM}$ and $\operatorname{IgG}$ in 18 serum samples, that of both IgM and NAb in 19 samples, and that of both IgG and NAb in 26 samples (Fig. 1B-a, -b and -c). Both IgM and $\operatorname{IgG}$ titres were significantly correlated with $\mathrm{NAb}$ $(P<0.01$ and $P<0.001$, respectively; Fig. 1B-d). Overall, IgM conversion exhibited an increase-decrease pattern (Fig. 1B-a), with $18 \%$ of the serum samples $(n=17)$ testing positive in week 1 and $54 \%(\mathrm{n}=13), 50 \%(\mathrm{n}=14)$ in weeks 2 and 3, respectively. After week 3, seroconversion of $\operatorname{IgM}$ decreased to $43 \%(n=7)$. IgG and $\mathrm{NAb}$ conversion exhibited a continually increasing trend. IgG had a low conversion rate of $24 \%(\mathrm{n}=17)$ in week 1 and $100 \%(\mathrm{n}=14)$ at 3 weeks later (Fig. 1B-b). In week 1 , $53 \%(\mathrm{n}=17)$ of the samples tested positive for NAb, increasing to $77 \%(\mathrm{n}=13)$ in week 2 , and $100 \%$ thereafter. The average IgM titre was low throughout the observation period, whereas the average $\operatorname{IgG}$ titre continued to increase at 3 weeks after symptom onset (Fig. 1B-e). IgG titres increased significantly in week 3 compared to week 1 $(P<0.01)$, and that were significantly higher after week 3 than that in week 1 and week $2(P<0.001$ and $P<0.01)$. NAb displayed special pattern with significantly higher levels in week 2 after symptom onset than that in week 1 $(P<0.05)$, while NAb titers in week 3 and 4 after symptom onset were not significantly higher than that in week 2 (Fig. 1B-e). IgM and IgG levels in the serum of eight patients were compared in a matched-pair analysis (Fig. 1B-f, -g). The dynamic changes of serum antibody titres exhibited diverse trends and occurred in most of the patients at 2 weeks after symptom onset. However, low IgM levels and a slow response was observed in one individual, and IgM levels in another patient decreased at 5 weeks after symptom onset, when a second serum sample was collected. By contrast, IgG levels in the second serum samples were significantly higher than in the first ones. The median seroconversion times were 14 (IgM and NAb) and $16(\mathrm{IgG})$ days after symptom onset, similar with the results in other studies (Demey et al. 2020; Imai et al. 2020; Lee et al. 2020; Liu et al. 2020; Lou et al. 2020; Norman et al. 2020; Okba et al. 2020; To et al. 2020).

In this single centre study, we investigated the profiles of SARS-CoV-2 RNA and antibodies of 53 COVID-19 patients with different clinical manifestation (Garbati et al. 2016; Lou et al. 2020; Xiang et al. 2020). The results proved that SARS-CoV-2 excretion via the respiratory tract was the main viral source, and the profiles of SARS-CoV-2 RNA and antibodies were not related with clinical manifestation. Notably, the dynamics of SARS-CoV-2 RNA were similar in asymptomatic COVID-19 patients with others, and this aspect should be studied in further detail. Our analysis of viral loads confirmed that some asymptomatic cases can host extraordinarily high viral loads, implying that asymptomatic patients who engage in social contact can have high transmission potential (Pan et al. 2020a; Zou et al. 2020). These cases should be managed 


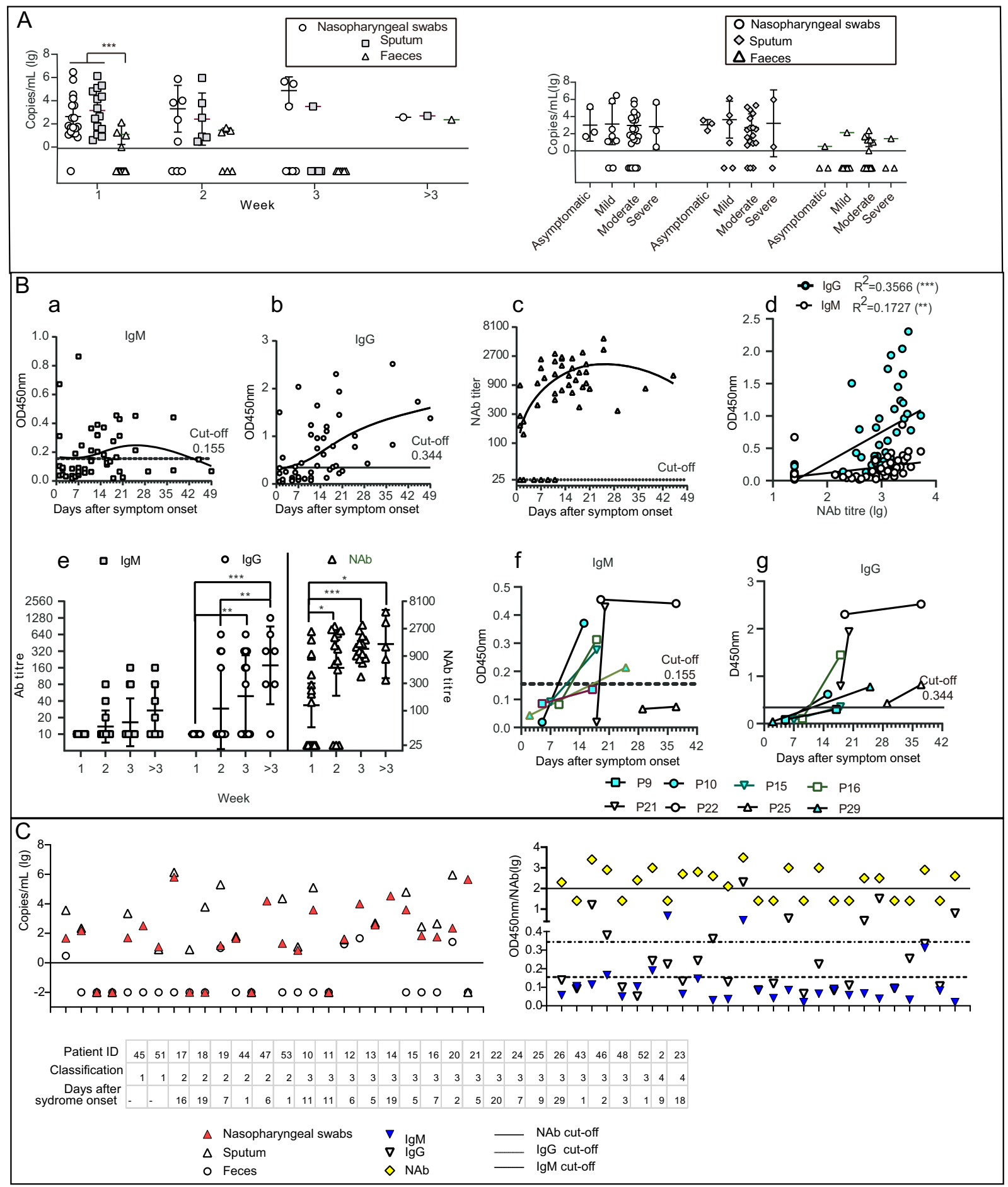

Fig. 1 Detection of viral RNA and antibodies in samples of COVID19 patients. A Comparison of viral RNA loads in COVID-19 patients detected by nasopharyngeal swab, sputum, and faecal samples (left) Viral RNA loads in COVID-19 patients with different clinical manifestations. B Serum IgM and IgG profiles in COVID-19 patients as analysed using RBD-based enzyme-linked immunosorbent assay (ELISA). a-c Cross-sectional profiles of absorbance at $450 \mathrm{~nm}$ (OD450nm) by $\operatorname{IgM}$ (a) and IgG (b) against RBD and by neutralising antibody (NAb) in a pseudovirus particle neutralisation test $(\mathbf{c})$. Each dot represents an individual serum sample. d, Comparison of IgM,
IgG, and NAb. e, Chronological changes (weeks after symptom onset) in IgM and IgG titres based on RBD-ELISA, and in NAb titres. $f$ and g Changes in $\operatorname{IgM}(\mathbf{f})$ and $\operatorname{IgG}(\mathbf{g})$ levels between matched pairs of serum samples from COVID-19 patients. Each line represents an individual patient. C Detection of viral RNA and antibodies in SARSCoV-2-infected patients. Results of matched-pair analysis to detect RNA (left) and antibody levels (right) in SARS-CoV-2-infected individuals. Classification: 1 indicated as asymptomatic patients, 2 indicated as mild patients, 3 indicated as moderate patients, 4 indicated as severe patients. $* P<0.05, * * P<0.01$, $* * * P<0.001$. 
early to prevent disease transmission (Joint Taskforce on Control 2020).

Although IgG and NAb levels increased over time, indicating seroconversion, no significant differences in $\mathrm{IgG}$ and NAb levels were found among COVID-19 patients with different clinical manifestations throughout the observation period. These results contradict previous studies (Long et al. 2020; Okba et al. 2020; Ozturk et al. 2020; Wang et al. 2020b, 2020c), considering the difference of longitudinal study and cross-sectional survey.

In this study, the matched-pair analysis indicated that the occurrences of the virus and antibodies were not mutually exclusive, suggesting that the development of antibodies in serum was not followed by the rapid elimination of viral RNA from the lung. NAb normally includes IgA, which is secreted in respiratory fluids and saliva (Hsueh et al. 2004; Norman et al. 2020; Okba et al. 2020). Further work by our group will focus on IgA detection.

A major limitation of this study was the limited number of patients enrolled from a single centre. Multicentre, multi-national, prospective studies on the profiles and dynamics of SARS-CoV-2 RNA and antibodies are urgently needed for prediction and diagnosis of the clinical progress and outcomes in COVID-19 patients. In addition, commercial antibody assays with the best performance in clinical settings should be chosen in future studies.

Acknowledgements This work was supported by the National Key Program for Infectious Disease of China (2018ZX10101002), the National Key Research and Development Program of China (2016YFD0500301, 2020YFC0840900).

\section{Compliance with Ethical Standards}

Conflict of interest The authors declare no competing interests.

Animal and Human Rights Statement All procedures performed in studies involving human participants were in accordance with the policy on public health investigations of emerging infectious diseases issued by the National Health Commission of China and its later amendments or comparable ethical standards.

\section{References}

Burbelo PD, Riedo FX, Morishima C, Rawlings S, Smith D, Das S, Strich JR, Chertow DS, Davey RT, Cohen JI (2020) Detection of nucleocapsid antibody to SARS-CoV-2 is more sensitive than antibody to Spike protein in COVID-19 patients. China CDC Weekly 9:469

Chinese Center for Disease Control and Prevention (2020) Technical guidelines for COVID-19 laboratory testing. China CDC Weekly. https://doi.org/10.46234/ccdcw2020.085

Demey B, Daher N, François C, Lanoix JP, Duverlie G, Castelain S, Brochot E (2020) Dynamic profile for the detection of antiSARS-CoV-2 antibodies using four immunochromatographic assays. J Infect S0163:30244-30249
Garbati MA, Fagbo SF, Fang VJ, Skakni L, Joseph M, Wani TA, Cowling BJ, Peiris M, Hakawi A (2016) A comparative study of clinical presentation and risk factors for adverse outcome in patients hospitalised with acute respiratory disease due to MERS coronavirus or other causes. PLoS ONE 11:1-12

Han H, Luo Q, Mo F, Long L, Zheng W (2020) SARS-CoV-2 RNA more readily detected in induced sputum than in throat swabs of convalescent COVID-19 patients. Lancet Infect Dis 3099:30174

Hsueh PR, Huang LM, Chen PJ, Kao CL, Yang PC (2004) Chronological evolution of IgM, IgA, IgG and neutralisation antibodies after infection with SARS-associated coronavirus. Clin Microbiol Infect 10:1062-1066

Imai K, Tabata S, Ikeda M, Noguchi S, Kitagawa Y, Matuoka M, Miyoshi K, Tarumoto N, Sakai J, Ito T, Maesaki S, Tamura K, Maeda T (2020) Clinical evaluation of an immunochromatographic IgM/IgG antibody assay and chest computed tomography for the diagnosis of COVID-19. J Clin Virol 128:1315

Lee CYP, Lin RTP, Renia L, Ng LFP (2020) Serological approaches for COVID-19: Epidemiologic perspective on surveillance and control. Front Immunol 11:1-7

Li Z, Yi Y, Luo X, Xiong N, Liu Y, Li S, Sun R, Wang Y, Hu B, Chen W, Zhang Y, Wang J, Huang B, Lin Y, Yang J, Cai W, Wang X, Cheng J, Chen Z, Sun K, Pan W, Zhan Z, Chen L, Ye F (2020) Development and clinical application of a rapid IgM-IgG combined antibody test for SARS-CoV-2 infection diagnosis. J Med Virol 92:1518-1524

Liu W, Liu L, Kou G, Zheng Y, Ding Y, Ni W, Wang Q, Tan L, Wu W, Tang S, Xiong Z, Zheng S (2020) Evaluation of nucleocapsid and spike protein-based enzyme-linked immunosorbent assays for detecting antibodies against SARS-CoV-2. J Clin Microbiol 58:e00461-e520

Long Q, Deng H, Chen J, Hu J, Liu B, Liao P, Lin Y, Yu L, Mo Z, Xu Y, Gong F, Wu G, Zhang X, Chen Y, Li Z, Wang K, Zhang X, Tian W, Niu C, Yang Q, Xiang J, Du H, Liu H, Lang C, Luo X, Wu S, Cui X, Zhou Z, Wang J, Xue C, Li X, Wang L, Tang X, Zhang Y, Qiu J, Liu X, Li J, Zhang D, Zhang F, Cai X, Wang D, Hu Y, Ren J, Tang N, Liu P, Li Q, Huang A (2020) Antibody responses to SARS-CoV-2 in COVID-19 patients: the perspective application of serological tests in clinical practice. medRxiv doi:2020.03.18.20038018

Lou B, Li T-D, Zheng S-F, Su Y-Y, Li Z-Y, Liu W, Yu F, Ge S-X, Zou Q-D, Yuan Q, Lin S, Hong C-M, Yao X-Y, Zhang X-J, Wu D-H, Zhou G-L, Hou W-H, Li T-T, Zhang Y-L, Zhang S-Y, Fan J, Zhang J, Xia N-S, Chen Y (2020) Serology characteristics of SARS-CoV-2 infection since exposure and post symptom onset. Eur Respir J 27:775

Lu R, Zou L, Wang Y, Zhao Y, Zhou W, Wu J, Wang W, Wu G, Ke C, Tan W (2015) Sequencing and phylogenetic analyses of structural and accessory proteins of Middle East respiratory syndrome coronavirus from the first imported case in China, 2015. Chinese J Virol 31:333-340

Nie J, Li Q, Wu J, Zhao C, Hao H, Liu H, Zhang L, Nie L, Qin H, Wang M, Lu Q, Li X, Sun Q, Liu J, Fan C, Huang W, Xu M, Wang Y (2020) Establishment and validation of a pseudovirus neutralization assay for SARS-CoV-2. Emerg Microbes Infect 9:680-686

Niu P, Lu R, Zhao L, Wang H, Huang B, Ye F, Wang W, Tan W (2020) Three novel real-time RT-PCR assays for detection of COVID-19 virus. China CDC Weekly. https://doi.org/10.46234/ ccdcw2020.116

Norman M, Gilboa T, Ogata AF, Maley AM, Cohen L, Cai Y, Zhang J, Feldman JE, Hauser BM, Caradonna TM, Chen B, Schmidt AG, Alter G, Charles RC, Ryan ET, Walt DR (2020) Ultrasensitive high-resolution profiling of anti-SARS-CoV-2 antibodies for detecting early seroconversion in COVID-19 patients. medRxiv doi:2020.04.28.20083691 
Okba N, Muller M, Li W, Wang C, GeurtsvanKessel C, Corman V, Lamers M, Sikkema R, de Bruin E, Chandler F, Yazdanpanah Y, Le Hingrat Q, Descamps D, Houhou-Fidouh N, Reusken C, Bosch B-J, Drosten C, Koopmans M, Haagmans B (2020) Severe acute respiratory syndrome coronavirus 2 -specific antibody responses in coronavirus disease patients. Emerg Infect Dis 26:1478-1488

Ozturk T, Howell C, Benameur K, Ramonell RP, Cashman K, Pirmohammed S, Bassit L, Roback J, Marconi VC, Schinazi RF, Wharton W, Lee FE-H, Hu WT (2020) Cross-sectional IgM and IgG profiles in SARS-CoV-2 infection. medRxiv doi:2020.05.10.20097535

Pan X, Chen D, Xia Y, Wu X, Li T, Ou X, Zhou L, Liu J (2020a) Asymptomatic cases in a family cluster with SARS-CoV-2 infection. Lancet Infect Dis 20:410-411

Pan Y, Zhang D, Yang P, Poon LLM, Wang Q (2020b) Viral load of SARS-CoV-2 in clinical samples. Lancet Infect Dis 20:411-412

Taskforce on C-P, Control CSC (2020) Protocol for the management of asymptomatic persons infected with COVID-19 virus. China CDC Weekly 2:1-2

To KKW, Tsang OTY, Leung WS, Tam AR, Wu TC, Lung DC, Yip CCY, Cai JP, Chan JMC, Chik TSH, Lau DPL, Choi CYC, Chen LL, Chan WM, Chan KH, Ip JD, Ng ACK, Poon RWS, Luo CT, Cheng VCC, Chan JFW, Hung IFN, Chen Z, Chen H, Yuen KY (2020) Temporal profiles of viral load in posterior oropharyngeal saliva samples and serum antibody responses during infection by SARS-CoV-2: an observational cohort study. Lancet Infect Dis 20:565-574

Wan Y, Li Z, Wang K, Li T, Liao P (2020) Performance verification of detecting COVID-19 specific antibody by using four chemiluminescence immunoassay systems. medRxiv doi: 2020.04.27.20074849

Wang W, Wang H, Deng Y, Song T, Lan J, Wu G, Ke C, Tan W (2016) Characterization of anti-MERS-CoV antibodies against various recombinant structural antigens of MERS-CoV in an imported case in China. Emerg Microbes Infect 5:e113-e116
Wang W, Wang T, Deng Y, Niu P, Ruhan A, Zhao J, PeirisN M, Tang S, Tan W (2019) A novel luciferase immunosorbent assay performs better than a commercial enzyme-linked immunosorbent assay to detect MERS-CoV specific IgG in humans and animals. Biosaf Heal 1:134-143

Wang W, Xu Y, Gao R, Lu R, Han K, Wu G, Tan W (2020a) Detection of SARS-CoV-2 in different types of clinical specimens. JAMA 323:1061-1069

Wang X, Guo X, Xin Q, Pan Y, Hu Y, Li J, Chu Y, Feng Y, Wang Q (2020b) Neutralizing antibodies responses to SARS-CoV-2 in COVID-19 inpatients and convalescent patients. Clin Infect Dis 71:2688-2694

Wang Y, Zhang L, Sang L, Ye F, Ruan S, Zhong B, Song T, Alshukairi AN, Chen R, Zhang Z, Gan M, Zhu A, Huang Y, Luo L, Mok CKP, Gethamy MMA, Tan H, Li Z, Huang X, Li F, Sun J, Zhang Y, Wen L, Li Y, Chen Z, Zhuang Z, Zhuo J, Chen C, Kuang L, Wang J, Lv H, Jiang Y, Li M, Lin Y, Deng Y, Tang L, Liang J, Huang J, Perlman S, Zhong N, Zhao J, Peiris M, Li Y, Zhao J (2020c) Kinetics of viral load and antibody response in relation to COVID-19severity. J Clin Invest 130(10):5235-5244

Xiang F, Wang X, He X, Peng Z, Yang B, Zhang J, Zhou Q, Ye H, Ma Y, Li H, Wei X, Cai P, Ma WL (2020) Antibody detection and dynamic characteristics in patients with COVID-19. Clin Infect Dis Ciaa. https://doi.org/10.1093/cid/ciaa721

Xu T, Chen C, Zhu Z, Cui M, Chen C, Dai H, Xue Y (2020) Clinical features and dynamics of viral load in imported and nonimported patients with COVID-19. Int J Infect Dis 94:68-71

Zhao R, Li M, Song H, Chen J, Ren W, Feng Y, Gao GF, Song J, Peng Y, Su B, Guo X, Wang Y, Chen J, Li J, Sun H, Bai Z, Cao WJ, Zhu J, Zhang Q, Sun Y, Sun S, Mao X, Su J, Chen X, He A, Gao W, Jin R, Jiang Y, Sun L (2020) Early detection of SARSCoV-2 antibodies in COVID-19 patients as a serologic marker of infection. Clin Infect Dis. https://doi.org/10.1093/cid/ciaa523

Zou L, Ruan F, Huang M, Liang L, Huang H, Hong Z, Yu J, Kang M, Song Y, Xia J, Guo Q, Song T, He J, Yen H-L, Peiris M, Wu J (2020) SARS-CoV-2 viral load in upper respiratory specimens of infected patients. N Engl J Med 382:1177-1179 